\title{
Analisis Penerapan Total Productive Maintenance Pada Industri Pipa Baja
}

\author{
Yopi Ramadhani Robi Putra ${ }^{1}$, Fuad Achmadi ${ }^{2}$ \\ ${ }^{1}$ Jurusan Teknik Industri, Fakultas Teknologi Industri, Institut Teknologi Adhi Tama Surabaya \\ ${ }^{2}$ Jurusan Teknik Industri, Fakultas Teknologi Industri, Institut Teknologi Nasional Malang \\ Email: 1'yopiramadhanirobi@gmail.com, ${ }^{2}$ fuadachmadi@gmail.com
}

\begin{abstract}
PT. ABC is a manufacturing industry engaged in the production of steel pipes. One of the dominant machines for production activities is the slitter machine. The maintenance system applied is preventive maintenance but the implementation is not optimal because slitter machines often experience maintenance breakdowns. Data for 12 months shows that the slitter machine experienced 1281 hours of downtime. This study aims to analyze the implementation of Total Productive Maintenance with the Overall Equpiment Effectiveness (OEE) approach and six big losses. OEE calculation results show a value of $75.9 \%$. There are two components that are still not good and are below world class standards, namely availability of $77.3 \%$ and quality of $98.7 \%$. And from the results of the analysis of the six big losses obtained dominant losses to the low value of availability is set up and adjustment with a percentage loss of $20 \%$.
\end{abstract}

Keywords: OEE, Six Big Losses, Slitter, TPM

\begin{abstract}
Abstrak
PT. ABC adalah industri manufaktur yang bergerak dalam bidang produksi pipa baja. Salah satu mesin yang dominan terhadap aktivitas produksiya adalah mesin slitter. Sistem perawatan yang diterapkan adalah preventive maintenance namun implementasinya belum optimal karena mesin slitter sering mengalami breakdown maintenance. Data selama 12 bulan menunjukkan bahwa mesin slitter mengalami 1281 jam downtime. Penelitian ini bertujuan untuk melakukan analisis penerapan Total Productive Maintenance dengan pendekatan Overall Equpiment Effectiveness (OEE) dan six big losses. Hasil perhitungan OEE menunjukkan nilai sebesar 75,9\%. Terdapat dua komponen yang masih kurang baik dan berada dibawah standar kelas dunia yaitu availability sebesar 77,3\% dan quality sebesar 98,7\%. Dan dari hasil analisis six big losses diperoleh losses yang dominan terhadap rendahnya nilai availability adalah set up and adjustment dengan persentase losses sebesar $20 \%$.
\end{abstract}

Kata Kunci: OEE, Six Big Losses, Slitter, TPM

\section{Pendahuluan}

Dalam upaya peningkatan produktivitas, dibutuhkan suatu mekanisme yang memiliki manfaat dalam peningkatan efisiensi mesin. Salah satu yang bisa diterapkan adalah Total Productive Maintenance (TPM) [1]. Total Productive Maintenance (TPM) adalah kegiatan perencanaan pemeliharaan peralatan dari aspek pemeriksaan, perbaikan kecil sampai perbaikan yang terencana dengan melibatkan semua personil yang terkait dengan pemeliharaan [2]. Filosofi yang dikandung oleh TPM memungkinkan bagi perusahaan untuk melakukan program pemeliharaan mesin/peralatan sehingga proses produksi dapat berjalan dengan efektif dan efisien. Melalui TPM perusahaan dapat menemukan potensi-potensi pemborosan yang ditimbulkan dari aktivitas produksinya.

PT. ABC adalah industri manufaktur yang bergerak dalam bidang produksi pipa baja. Produk yang dihasilkan adalah pipa baja jenis bulat dan jenis kotak dengan ketebalan sesuai permintaan pelanggan dan standart yang berlaku. Produk yang dihasilkan banyak digunakan untuk proyek pembangunan dalam Negeri maupun swasta dan sebagian lainnya dieksport untuk memenuhi kebutuhan pasar luar negeri. Dalam melakukan aktivitas produksinya PT. ABC kerap kali menemui permasalahan yang berkaitan dengan mesin dan peralatan yang digunakan. Peralatan yang digunakan 
dalam proses produksi berjalan 24 jam non-stop, sehingga efektivitas dan efisiensi peralatan menjadi hal yang sangat diutamakan. Salah satu stasiun kerja yang memberikan peran penting terhadap kelangsungan proses produksi pada PT. ABC adalah mesin slitter. Pada stasiun kerja tersebut dilakukan proses pemotongan baja gulungan (coil) secara memanjang/longitudinal sesuai dengan lebar yang dibutuhkan untuk bahan baku pembuatan pipa baja. Mesin bekerja berdasarkan order yang diturunkan oleh pihak PPIC. Semakin banyak order yang ada maka mesin dituntut supaya selalu siap ketika dibutuhkan, sehingga produktivitas mesin perlu untuk diukur dan diketahui sampai sejauh mana tingkatannya.

Sistem perawatan yang diterapkan pada PT. ABC adalah preventive maintenance namun implementasinya belum optimal karena mesin slitter sering mengalami breakdown maintenance. Tentu hal tersebut akan berdampak pada pemborosan waktu yang ditimbulkan dari perawatan yang dilakukan karena jenis kerusakan yang terjadi bisa saja berat sehingga membutuhkan waktu yang lebih lama dalam proses perbaikan, sehingga dapat menghambat produktivitas mesin. Sistem perawatan memegang peranan penting dalam dunia industri. Bahkan perusahaan akan mengalami kerugian besar jika tidak memperhatikan perawatan dengan baik, seperti terjadinya kerusakan mesin, meningkatnya produk cacat, intensitas penggantian komponen yang terlalu sering [3].

Tujuan dari penelitian ini adalah melakukan analisis penerapan Total Productive Maintenance dengan pendekatan OEE (Overall Equipment Effectiveness) dan six big losses serta memberikan usulan perbaikan yang terbaik untuk efektifitas perawatan sehingga produktifitas dapat dicapai.

\section{Metode}

Metodologi penelitian menggambarkan tahap-tahap yang dilakukan oleh peneliti dalam melakukan penelitian. Tahap awal dimulai dengan proses identifikasi masalah di PT. ABC, tahap kedua adalah studi pustaka dan observasi lapangan untuk mengumpulkan informasi terkait teori dan metode pendekatan dalam menyelesaikan persoalan. Tahap ketiga adalah identifikasi dan pengumpulan data (data primer dan data sekunder). Selanjutnya dilakukan tahap pengolahan data dan dilakukan perhitungan availability rate, performance rate, dan quality rate sehingga bisa didapatkan nilai OEE dan six big losses. Setelah pengolahan data dilakukan lanjut pada tahap pembahasan dan analisa. Sampai dengan tahap akhir yaitu usulan perbaikan yang diberikan dan kesimpulan.

Tahapan alur penelitian diuraikan pada gambar berikut:
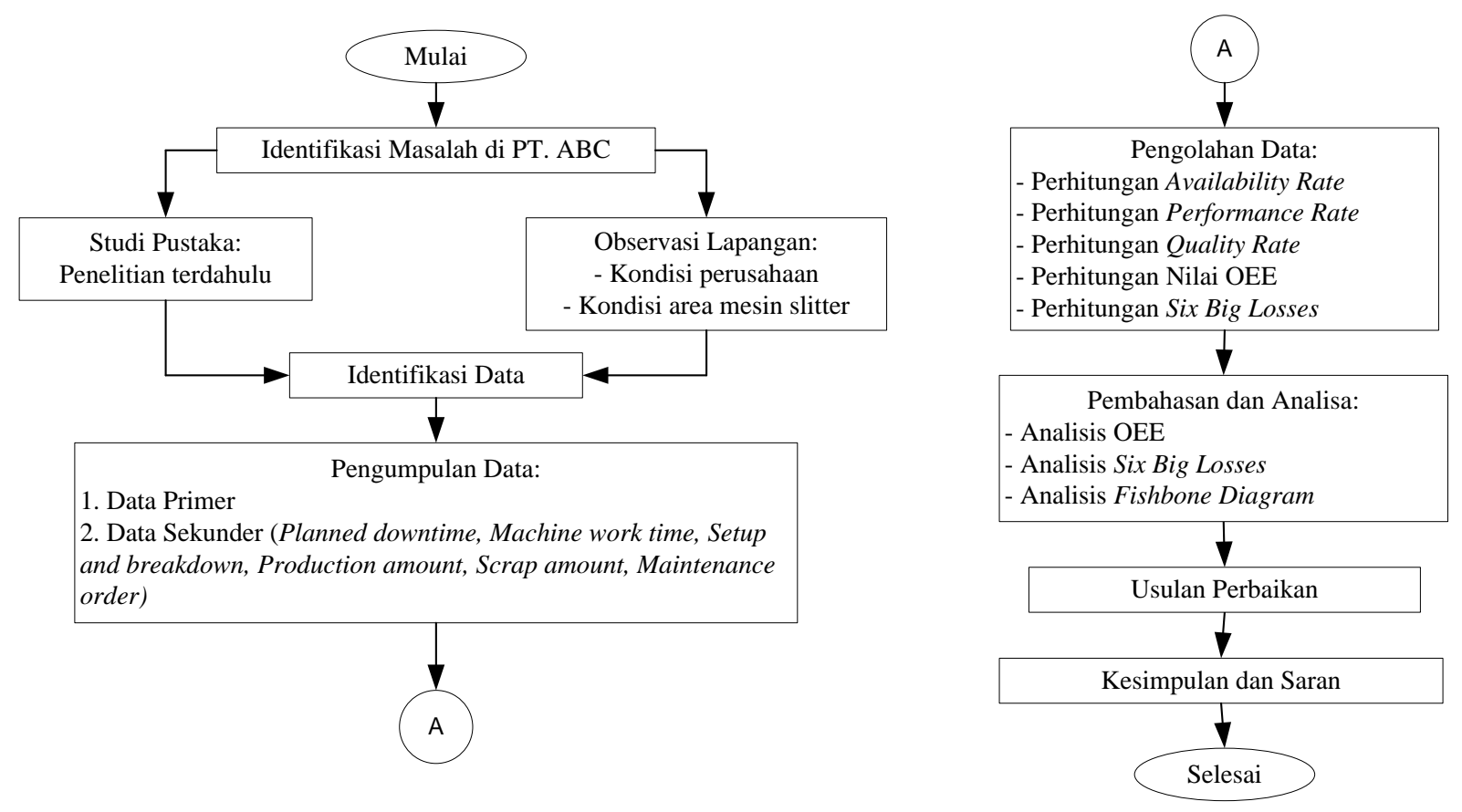

Gambar 1. Tahapan proses penelitian 


\section{Hasil dan Pembahasan}

Seperti yang telah diuraikan pada tahapan proses penelitian diatas, bahwa penelitian dimulai dengan pengumpulan data historis yang menunjang untuk dilakukan perhitungan OEE dan six big losses, dimana data historis yang dimaksud adalah planned downtime, set up and ajusment, dan breakdown time.

Tabel 1. Data Planned Downtime

\begin{tabular}{cccc} 
No & Bulan & Planned Downtime (Menit) & Planned Downtime (Jam) \\
\hline 1 & November 2018 & 120 & 2 \\
\hline 2 & Desember 2018 & 90 & 1.5 \\
\hline 3 & Januari 2019 & 150 & 2.5 \\
\hline 4 & Februari 2019 & 90 & 1.5 \\
\hline 5 & Maret 2019 & 120 & 2 \\
\hline 6 & April 2019 & 150 & 2.5 \\
\hline 7 & Mei 2019 & 90 & 1.5 \\
\hline 8 & Juni 2019 & 180 & 3 \\
\hline 9 & Juli 2019 & 150 & 2.5 \\
\hline 10 & Agustus 2019 & 120 & 2 \\
\hline 11 & September 2019 & 150 & 2.5 \\
\hline 12 & Oktober 2019 & 150 & 2.5 \\
\hline
\end{tabular}

Tabel 2. Data Set Up and Adjustment

\begin{tabular}{cccc} 
No & Bulan & Set Up and Adjusment (Menit) & Set Up and Adjusment (Jam) \\
\hline 1 & November 2018 & 5110 & 85.17 \\
\hline 2 & Desember 2018 & 6120 & 102 \\
\hline 3 & Januari 2019 & 4995 & 83.25 \\
\hline 4 & Februari 2019 & 4850 & 80.83 \\
\hline 5 & Maret 2019 & 5040 & 84 \\
\hline 6 & April 2019 & 5715 & 95.25 \\
\hline 7 & Mei 2019 & 5400 & 90 \\
\hline 8 & Juni 2019 & 2715 & 45.25 \\
\hline 9 & Juli 2019 & 6270 & 104.5 \\
\hline 10 & Agustus 2019 & 7050 & 117.5 \\
\hline 11 & September 2019 & 6625 & 110.42 \\
\hline 12 & Oktober 2019 & 6990 & 116.5 \\
\hline
\end{tabular}


Tabel 3. Data Breakdown

\begin{tabular}{cccc}
\hline No & Bulan & Breakdown (Menit) & Breakdown (Jam) \\
\hline 1 & November 2018 & 1230 & 20.5 \\
\hline 2 & Desember 2018 & 1860 & 31 \\
\hline 3 & Januari 2019 & 415.2 & 6.92 \\
\hline 4 & Februari 2019 & 345 & 5.75 \\
\hline 5 & Maret 2019 & 445.2 & 7.42 \\
\hline 6 & April 2019 & 480 & 8 \\
\hline 7 & Mei 2019 & 435 & 7.25 \\
\hline 8 & Juni 2019 & 1830 & 30.5 \\
\hline 9 & Juli 2019 & 79.8 & 1.33 \\
\hline 10 & Agustus 2019 & 330 & 5.5 \\
\hline 11 & September 2019 & 469.8 & 7.83 \\
\hline 12 & Oktober 2019 & 510 & 8.5 \\
\hline
\end{tabular}

Setelah data-data penunjang dihimpun, selanjutnya adalah melakukan analisis perhitungan availability, performance, dan quality. Availability ratio merupakan suatu perbandingan yang menggambarkan pemanfaatan waktu yang tersedia untuk kegiatan operasi mesin atau peralatan [4].

Availability $=\frac{\text { operation Time }}{\text { Loading Time }} \times 100 \%$

Tabel 4. Hasil Perhitungan Availability Mesin Slitter

\begin{tabular}{cccccccc}
\hline No & Bulan & $\begin{array}{c}\text { Waktu } \\
\text { Kerja } \\
\text { Mesin } \\
(\mathbf{J a m})\end{array}$ & $\begin{array}{c}\text { Planned } \\
\text { Downtime } \\
(\mathbf{J a m})\end{array}$ & $\begin{array}{c}\text { Total } \\
\text { Downtime } \\
(\mathbf{J a m})\end{array}$ & $\begin{array}{c}\text { Loading } \\
\text { Time } \\
(\mathbf{J a m})\end{array}$ & $\begin{array}{c}\text { Operating } \\
\text { Time }(\mathrm{Jam})\end{array}$ & $\begin{array}{c}\text { Availability } \\
(\%)\end{array}$ \\
\hline 1 & November 2018 & 428.0 & 2 & 105.7 & 426 & 320.3 & $75.2 \%$ \\
\hline 2 & Desember 2018 & 457.0 & 1.5 & 133.0 & 456 & 322.5 & $70.8 \%$ \\
\hline 3 & Januari 2019 & 413.0 & 2.5 & 90.2 & 411 & 320.3 & $78.0 \%$ \\
\hline 4 & Februari 2019 & 374.0 & 1.5 & 86.6 & 373 & 285.9 & $76.8 \%$ \\
\hline 5 & Maret 2019 & 479.0 & 2 & 91.4 & 477 & 385.6 & $80.8 \%$ \\
\hline 6 & April 2019 & 434.5 & 2.5 & 103.3 & 432 & 328.8 & $76.1 \%$ \\
\hline 7 & Mei 2019 & 502.5 & 1.5 & 97.3 & 501 & 403.8 & $80.6 \%$ \\
\hline 8 & Juni 2019 & 374.0 & 3 & 75.8 & 371 & 295.3 & $79.6 \%$ \\
\hline 9 & Juli 2019 & 570.0 & 2.5 & 105.8 & 568 & 461.7 & $81.4 \%$ \\
\hline 10 & Agustus 2019 & 539.5 & 2 & 123.0 & 538 & 414.5 & $77.1 \%$ \\
\hline 11 & September 2019 & 501.0 & 2.5 & 118.2 & 499 & 380.3 & $76.3 \%$ \\
\hline 12 & Oktober 2019 & 500.5 & 2.5 & 125.0 & 498 & 373.0 & $74.9 \%$ \\
\hline
\end{tabular}

Performance ratio adalah rasio yang merepresentasikan kemampuan dari mesin atau peralatan dalam menghasilkan produk/barang.

Performance ratio $=\frac{\text { Processed amount } x \text { Ideal cycle time }}{\text { Operation Time }} \times 100 \%$ 
Tabel 5. Perhitungan Performance Efficiency

\begin{tabular}{cccccc}
\hline No & Bulan & $\begin{array}{c}\text { Jumlah } \\
\text { Produksi } \\
\text { (Ton) }\end{array}$ & $\begin{array}{c}\text { Waktu Siklus } \\
\text { Ideal } \\
\text { (Jam/Ton) }\end{array}$ & $\begin{array}{c}\text { Operating } \\
\text { Time (Jam) }\end{array}$ & $\begin{array}{c}\text { Performance } \\
\text { (\%) }\end{array}$ \\
\hline 1 & November 2018 & 3385.8 & 0.094 & 320.3 & $99.5 \%$ \\
\hline 2 & Desember 2018 & 3194.7 & 0.101 & 322.5 & $99.7 \%$ \\
\hline 3 & Januari 2019 & 2462.0 & 0.129 & 320.3 & $99.4 \%$ \\
\hline 4 & Februari 2019 & 2970.1 & 0.096 & 285.9 & $99.6 \%$ \\
\hline 5 & Maret 2019 & 4945.5 & 0.078 & 385.6 & $99.6 \%$ \\
\hline 6 & April 2019 & 3606.6 & 0.091 & 328.8 & $99.4 \%$ \\
\hline 7 & Mei 2019 & 5334.5 & 0.075 & 403.8 & $99.7 \%$ \\
\hline 8 & Juni 2019 & 3120.6 & 0.094 & 295.3 & $99.2 \%$ \\
\hline 9 & Juli 2019 & 5495.1 & 0.084 & 461.7 & $99.6 \%$ \\
\hline 10 & Agustus 2019 & 4735.9 & 0.087 & 414.5 & $99.6 \%$ \\
\hline 11 & September 2019 & 4786.5 & 0.079 & 380.3 & $99.5 \%$ \\
\hline 12 & Oktober 2019 & 4542.7 & 0.082 & 373.0 & $99.5 \%$ \\
\hline
\end{tabular}

Quality ratio adalah rasio yang menggambarkan kemampuan mesin/peralatan dalam menghasilkan produk/barang yang sesuai dengan standar yang telah ditetapkan.

Quality ratio $=\frac{\text { Processed Amount } x \text { Defect Amount }}{\text { Processed Amount }} \times 100 \%$

Tabel 6. Hasil Perhitungan Quality

\begin{tabular}{cccccc}
\hline No & Bulan & $\begin{array}{c}\text { Jumlah Produksi } \\
\text { Kotor (Ton) }\end{array}$ & Produk Baik (Ton) & Afval (Ton) & $\begin{array}{c}\text { Quality } \\
(\%)\end{array}$ \\
\hline 1 & November 2018 & $3,385.77$ & $3,343.61$ & 42.16 & $98.8 \%$ \\
\hline 2 & Desember 2018 & $3,194.71$ & $3,147.54$ & 47.16 & $98.5 \%$ \\
\hline 3 & Januari 2019 & $2,461.96$ & $2,424.13$ & 37.83 & $98.5 \%$ \\
\hline 4 & Februari 2019 & $2,970.13$ & $2,916.42$ & 53.71 & $98.2 \%$ \\
\hline 5 & Maret 2019 & $4,945.50$ & $4,872.47$ & 73.03 & $98.5 \%$ \\
\hline 6 & April 2019 & $3,606.57$ & $3,553.64$ & 52.94 & $98.5 \%$ \\
\hline 7 & Mei 2019 & $5,334.53$ & $5,260.42$ & 74.12 & $98.6 \%$ \\
\hline 8 & Juni 2019 & $3,120.58$ & $3,080.48$ & 40.09 & $98.7 \%$ \\
\hline 9 & Juli 2019 & $5,495.12$ & $5,429.00$ & 66.12 & $98.8 \%$ \\
\hline 10 & Agustus 2019 & $4,735.94$ & $4,687.91$ & 48.03 & $99.0 \%$ \\
\hline 11 & September 2019 & $4,786.51$ & $4,740.49$ & 46.02 & $99.0 \%$ \\
\hline 12 & Oktober 2019 & $4,542.71$ & $4,500.71$ & 42.01 & $99.1 \%$ \\
\hline
\end{tabular}

Setelah availability, performance, dan quality didapatkan maka selanjutnya dapat diperoleh nilai OEE.

OEE $=$ Availability Ratio $\times$ Performance Ratio $\times$ Quality Ratio 
Tabel 7. Hasil Perhitungan Nilai OEE

\begin{tabular}{cccccc}
\hline No & Bulan & $\begin{array}{c}\text { Availability } \\
(\boldsymbol{\%})\end{array}$ & $\begin{array}{c}\text { Performance } \\
(\boldsymbol{\%})\end{array}$ & $\begin{array}{c}\text { Quality } \\
(\%)\end{array}$ & $\begin{array}{c}\text { OEE } \\
(\%)\end{array}$ \\
\hline 1 & November 2018 & $75.2 \%$ & $99.5 \%$ & $98.8 \%$ & $73.9 \%$ \\
\hline 2 & Desember 2018 & $70.8 \%$ & $99.7 \%$ & $98.5 \%$ & $69.5 \%$ \\
\hline 3 & Januari 2019 & $78.0 \%$ & $99.4 \%$ & $98.5 \%$ & $76.4 \%$ \\
\hline 4 & Februari 2019 & $76.8 \%$ & $99.6 \%$ & $98.2 \%$ & $75.1 \%$ \\
\hline 5 & Maret 2019 & $80.8 \%$ & $99.6 \%$ & $98.5 \%$ & $79.3 \%$ \\
\hline 6 & April 2019 & $76.1 \%$ & $99.4 \%$ & $98.5 \%$ & $74.6 \%$ \\
\hline 7 & Mei 2019 & $80.6 \%$ & $99.7 \%$ & $98.6 \%$ & $79.2 \%$ \\
\hline 8 & Juni 2019 & $79.6 \%$ & $99.2 \%$ & $98.7 \%$ & $77.9 \%$ \\
\hline 9 & Juli 2019 & $81.4 \%$ & $99.6 \%$ & $98.8 \%$ & $80.0 \%$ \\
\hline 10 & Agustus 2019 & $77.1 \%$ & $99.6 \%$ & $99.0 \%$ & $76.1 \%$ \\
\hline 11 & September 2019 & $76.3 \%$ & $99.5 \%$ & $99.0 \%$ & $75.2 \%$ \\
\hline 12 & Oktober 2019 & $74.9 \%$ & $99.5 \%$ & $99.1 \%$ & $73.8 \%$ \\
\hline & Rata-rata & $77.3 \%$ & $99.5 \%$ & $98.7 \%$ & $75.9 \%$ \\
\hline
\end{tabular}

Hasil perhitungan rata-rata nilai OEE mesin Slitter pada PT. ABC selama periode November 2018 - Oktober 2019 didapatkan sebesar 75,9\% dan menurut [5] nilai tersebut masuk dalam kategori sedang $(60 \%-84 \%)$. Terdapat selisih sebesar 9,1\% untuk bisa mencapai OEE kelas dunia yaitu $85 \%$. Untuk bisa mencapai nilai OEE 85\%, masing-masing komponen penyusun harus memenuhi standar minimal yang dipersyaratkan, availability minimal 90\%, performance minimal 95\%, dan quality minimal 99\% [6]. Nilai yang didapatkan pada mesin Slitter PT. ABC adalah availability sebesar $77,3 \%$, performance sebesar $99,5 \%$, dan quality sebesar 98,7\%. Pada availability terdapat selisih sebesar $12,7 \%$ untuk bisa mencapai batas minimal yang ditentukan (90\%). Pada performance sudah menunjukkan nilai yang baik dan melebihi batas minimal yang ditentukan (95\%). Pada quality terdapat selisih sebesar 0,3\% untuk bisa mencapai batas minimal yang ditentukan (99\%).

Setelah nilai OEE diperoleh analisis selanjutnya adalah menghitung six big losses. Pengukuran nilai six big losses adalah tindakan yang dilakukan tidak hanya fokus pada pencegahan kegagalan, tetapi juga untuk meminimalkan downtime mesin [7].

Tabel 8. Hasil Perhitungan Nilai Breakdown Losses

\begin{tabular}{ccccc}
\hline No & Bulan & $\begin{array}{c}\text { Breakdown } \\
(\text { Jam) }\end{array}$ & $\begin{array}{c}\text { Loading } \\
\text { Time }(J a m)\end{array}$ & $\begin{array}{c}\text { Breakdown } \\
\text { Losses (\%) }\end{array}$ \\
\hline 1 & November 2018 & 20.50 & 426 & $4.8 \%$ \\
\hline 2 & Desember 2018 & 31.00 & 455.5 & $6.8 \%$ \\
\hline 3 & Januari 2019 & 6.92 & 410.5 & $1.7 \%$ \\
\hline 4 & Februari 2019 & 5.75 & 372.5 & $1.5 \%$ \\
\hline 5 & Maret 2019 & 7.42 & 477 & $1.6 \%$ \\
\hline 6 & April 2019 & 8.00 & 432 & $1.9 \%$ \\
\hline 7 & Mei 2019 & 7.25 & 501 & $1.4 \%$ \\
\hline 8 & Juni 2019 & 30.50 & 371 & $8.2 \%$ \\
\hline 9 & Juli 2019 & 1.33 & 567.5 & $0.2 \%$ \\
\hline 10 & Agustus 2019 & 5.50 & 537.5 & $1.0 \%$ \\
\hline 11 & September 2019 & 7.83 & 498.5 & $1.6 \%$ \\
\hline 12 & Oktober 2019 & 8.50 & 498 & $1.7 \%$ \\
\hline
\end{tabular}


Tabel 9. Hasil Perhitungan Nilai Set Up and Adjusment Losses

\begin{tabular}{ccccc}
\hline No & Bulan & $\begin{array}{c}\text { Set Up and } \\
\text { Adjusment } \\
\text { (Jam) }\end{array}$ & $\begin{array}{c}\text { Loading } \\
\text { Time (Jam) }\end{array}$ & $\begin{array}{c}\text { Set Up and } \\
\text { Adjusment } \\
\text { Losses (\%) }\end{array}$ \\
\hline 1 & November 2018 & 85.17 & 426 & $20.0 \%$ \\
\hline 2 & Desember 2018 & 102.00 & 455.5 & $22.4 \%$ \\
\hline 3 & Januari 2019 & 83.25 & 410.5 & $20.3 \%$ \\
\hline 4 & Februari 2019 & 80.83 & 372.5 & $21.7 \%$ \\
\hline 5 & Maret 2019 & 84.00 & 477 & $17.6 \%$ \\
\hline 6 & April 2019 & 95.25 & 432 & $22.0 \%$ \\
\hline 7 & Mei 2019 & 90.00 & 501 & $18.0 \%$ \\
\hline 8 & Juni 2019 & 45.25 & 371 & $12.2 \%$ \\
\hline 9 & Juli 2019 & 104.50 & 567.5 & $18.4 \%$ \\
\hline 10 & Agustus 2019 & 117.50 & 537.5 & $21.9 \%$ \\
\hline 11 & September 2019 & 110.42 & 498.5 & $22.1 \%$ \\
\hline 12 & Oktober 2019 & 116.50 & 498 & $23.4 \%$ \\
\hline
\end{tabular}

Tabel 10. Hasil Perhitungan Reduced Speed Losses

\begin{tabular}{cccccccc}
\hline No & Bulan & $\begin{array}{c}\text { Operating } \\
\text { Time (Jam) }\end{array}$ & $\begin{array}{c}\text { Waktu } \\
\text { Siklus Ideal } \\
(\mathbf{J a m} / \text { Ton) }\end{array}$ & $\begin{array}{c}\text { Jumlah } \\
\text { Produksi } \\
(\text { Ton) }\end{array}$ & $\begin{array}{c}\text { Loading } \\
\text { Time } \\
(\mathbf{J a m})\end{array}$ & $\begin{array}{c}\text { Reduce } \\
\text { Speed } \\
\text { Loss } \\
(\mathbf{J a m})\end{array}$ & $\begin{array}{c}\text { Reduce } \\
\text { Speed } \\
\text { Loss }(\%)\end{array}$ \\
\hline 1 & November 2018 & 320.3 & 0.094 & 3385.8 & 426.0 & 1.50 & $0.35 \%$ \\
\hline 2 & Desember 2018 & 322.5 & 0.101 & 3194.7 & 455.5 & 1.06 & $0.23 \%$ \\
\hline 3 & Januari 2019 & 320.3 & 0.129 & 2462.0 & 410.5 & 1.94 & $0.47 \%$ \\
\hline 4 & Februari 2019 & 285.9 & 0.096 & 2970.1 & 372.5 & 1.15 & $0.31 \%$ \\
\hline 5 & Maret 2019 & 385.6 & 0.078 & 4945.5 & 477.0 & 1.61 & $0.34 \%$ \\
\hline 6 & April 2019 & 328.8 & 0.091 & 3606.6 & 432.0 & 1.89 & $0.44 \%$ \\
\hline 7 & Mei 2019 & 403.8 & 0.075 & 5334.5 & 501.0 & 1.21 & $0.24 \%$ \\
\hline 8 & Juni 2019 & 295.3 & 0.094 & 3120.6 & 371.0 & 2.37 & $0.64 \%$ \\
\hline 9 & Juli 2019 & 461.7 & 0.084 & 5495.1 & 567.5 & 2.02 & $0.36 \%$ \\
\hline 10 & Agustus 2019 & 414.5 & 0.087 & 4735.9 & 537.5 & 1.54 & $0.29 \%$ \\
\hline 11 & September 2019 & 380.3 & 0.079 & 4786.5 & 498.5 & 1.90 & $0.38 \%$ \\
\hline 12 & Oktober 2019 & 373.0 & 0.082 & 4542.7 & 498.0 & 1.86 & $0.37 \%$ \\
\hline
\end{tabular}

Tabel 11. Hasil Perhitungan Idling and Minor Stoppages

\begin{tabular}{ccccc}
\hline No & Bulan & $\begin{array}{c}\text { Nonproductive } \\
\text { time }(\mathbf{J a m})\end{array}$ & $\begin{array}{c}\text { Loading Time } \\
(\mathbf{J a m})\end{array}$ & $\begin{array}{c}\text { Idling and Minor } \\
\text { Stoppages }(\%)\end{array}$ \\
\hline 1 & November 2018 & 8.9 & 426 & $2.09 \%$ \\
\hline 2 & Desember 2018 & 9.5 & 456 & $2.09 \%$ \\
\hline 3 & Januari 2019 & 8.6 & 411 & $2.10 \%$ \\
\hline 4 & Februari 2019 & 7.8 & 373 & $2.09 \%$ \\
\hline 5 & Maret 2019 & 3.0 & 477 & $0.63 \%$ \\
\hline 6 & April 2019 & 2.7 & 432 & $0.63 \%$ \\
\hline 7 & Mei 2019 & 10.5 & 501 & $2.09 \%$ \\
\hline 8 & Juni 2019 & 7.8 & 371 & $2.10 \%$ \\
\hline 9 & Juli 2019 & 0.6 & 568 & $0.10 \%$ \\
\hline 10 & Agustus 2019 & 2.2 & 538 & $0.42 \%$ \\
\hline 11 & September 2019 & 2.1 & 499 & $0.42 \%$ \\
\hline 12 & Oktober 2019 & 3.1 & 498 & $0.63 \%$ \\
\hline
\end{tabular}


Tabel 12. Hasil Perhitungan Scrap Losses

\begin{tabular}{cccccc}
\hline No & Bulan & $\begin{array}{c}\text { Waktu Siklus } \\
\text { Ideal } \\
\text { (Jam/Ton) }\end{array}$ & Scrap (Ton) & $\begin{array}{c}\text { Loading Time } \\
(\mathbf{J a m})\end{array}$ & $\begin{array}{c}\text { Scrap Losses } \\
(\%)\end{array}$ \\
\hline 1 & November 2018 & 0.094 & 42.16 & 426.0 & $0.93 \%$ \\
\hline 2 & Desember 2018 & 0.101 & 47.16 & 455.5 & $1.04 \%$ \\
\hline 3 & Januari 2019 & 0.129 & 37.83 & 410.5 & $1.19 \%$ \\
\hline 4 & Februari 2019 & 0.096 & 53.71 & 372.5 & $1.38 \%$ \\
\hline 5 & Maret 2019 & 0.078 & 73.03 & 477.0 & $1.19 \%$ \\
\hline 6 & April 2019 & 0.091 & 52.94 & 432.0 & $1.11 \%$ \\
\hline 7 & Mei 2019 & 0.075 & 74.12 & 501.0 & $1.12 \%$ \\
\hline 8 & Juni 2019 & 0.094 & 40.09 & 371.0 & $1.01 \%$ \\
\hline 9 & Juli 2019 & 0.084 & 66.12 & 567.5 & $0.97 \%$ \\
\hline 10 & Agustus 2019 & 0.087 & 48.03 & 537.5 & $0.78 \%$ \\
\hline 11 & September 2019 & 0.079 & 46.02 & 498.5 & $0.73 \%$ \\
\hline 12 & Oktober 2019 & 0.082 & 42.01 & 498.0 & $0.69 \%$ \\
\hline
\end{tabular}

Hasil pengukuran nilai six big losses menujukkan nilai yang bermacam-macam. Berikut grafik persentase losses yang dihasilkan:

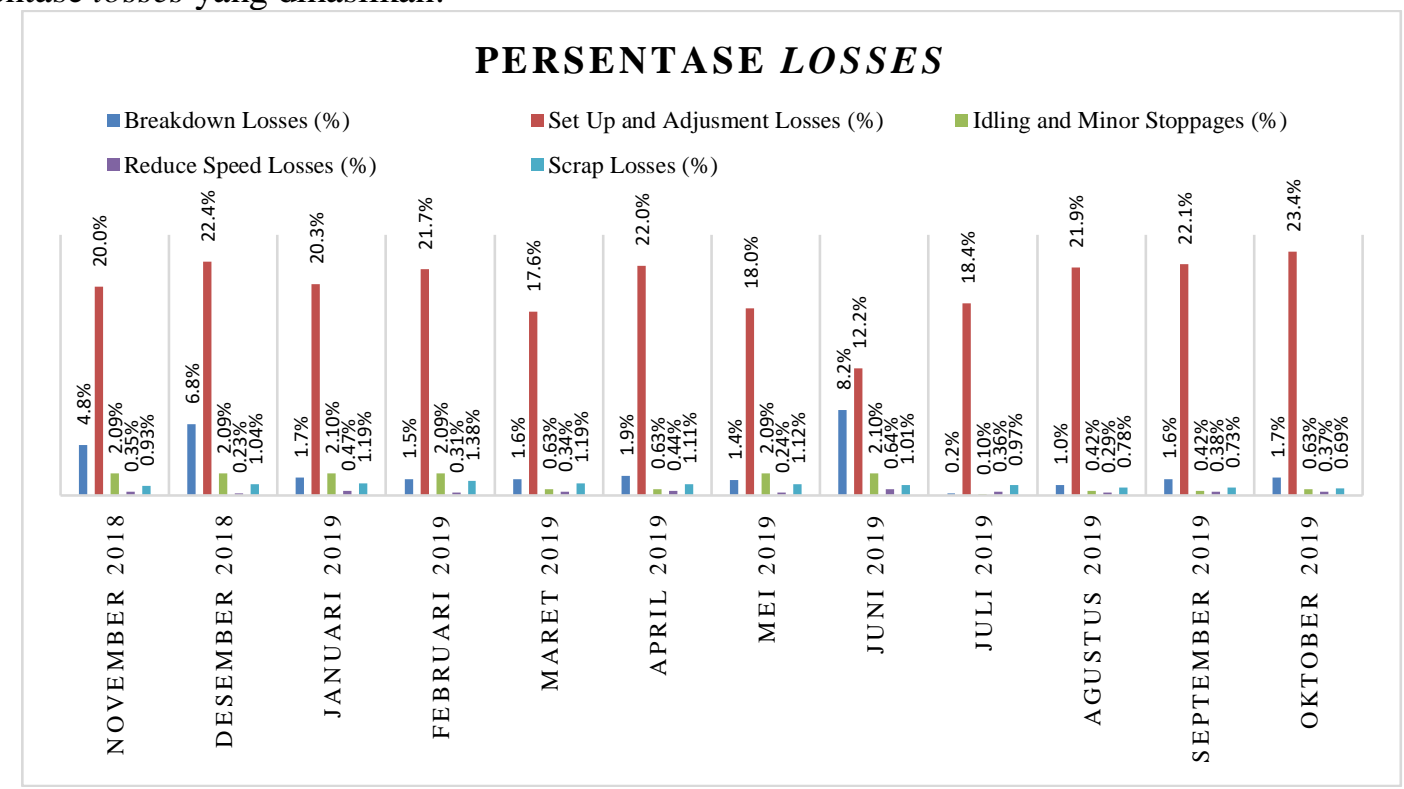

Gambar 2. Grafik nilai Losses

Gambar 2 dapat dilihat bahwa yang mendominasi losses dengan persentase tertinggi adalah set up and adjustment yakni dengan losses rata-rata sebesar 20\%. Tingginya nilai set up and adjustment losses pada mesin slitter menjadi penyebab utama belum optimalnya nilai OEE yang dihasilkan. Pengurangan nilai availability (ketersediaan waktu) pada akhirnya akan menurunkan efektivitas mesin pada stasiun slitter PT. ABC sehingga pada tahap selanjutnya perlu dilakukan identifikasi terhadap penyebab munculnya losses tersebut. Fishbone diagram pada gambar 3 digunakan untuk menelusuri sumber permasalahan yang menjadi sebab rendahnya nilai availability pada mesin slitter. 


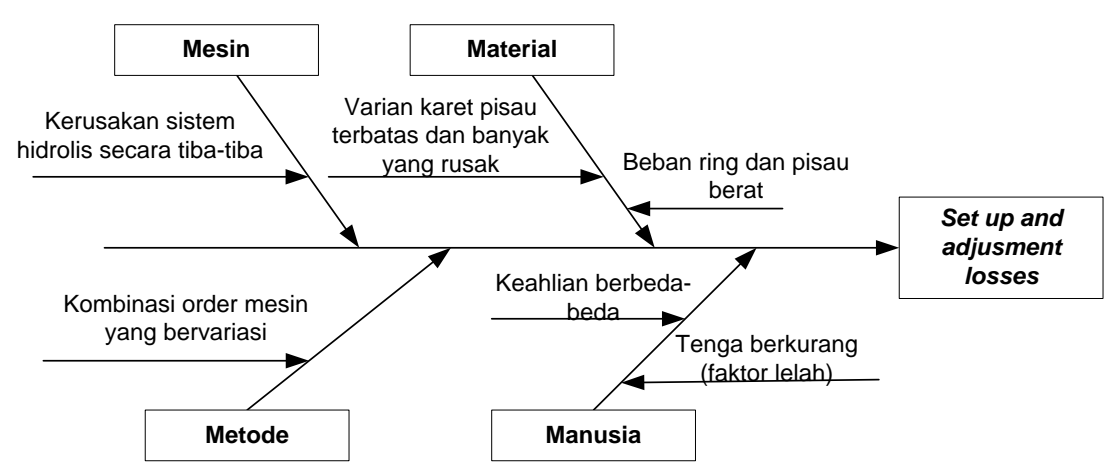

Gambar 3. Diagram fishbone

Berdasarkan hasil analisis diagram fishbone selanjutnya diperlukan usulan perbaikan guna meminimalkan downtime yang disebabkan oleh tingginya nilai set up and adjustment losses.

Tabel 13. Usulan Perbaikan

\begin{tabular}{|c|c|c|}
\hline No & Faktor-Faktor & Usulan Penyelesaian Masalah \\
\hline 1 & Manusia & $\begin{array}{l}\text { - Pembekalan pengetahuan dan kemampuan (training) kepada semua operator } \\
\text { mesin slitter. } \\
\text { - Pembagian job desc pekerjaan dimesin sehingga lebih menghemat tenaga. }\end{array}$ \\
\hline 2 & Metode & $\begin{array}{l}\text { Koordinasi dengan pihak pemberi order (PPIC) terkait dengan kombinasi order } \\
\text { mesin dan menetapkan standar waktu untuk pembongkaran masing-masing } \\
\text { order sesuai tingkat kesulitannya. }\end{array}$ \\
\hline 3 & Mesin & $\begin{array}{l}\text { - Pembekalan pengetahuan kepada operator terkait pemeliharaan ringan yang } \\
\text { harus dilakukan pada komponen hidrolis. } \\
\text { - Koordinasi dengan bagian pemeliharaan untuk lebih intens ketika melakukan } \\
\text { tindakan perbaikan prefentif sehingga komponen hidrolis yang vital tidak } \\
\text { sampai rusak secara mendadak ketika mesin sedang dibutuhkan untuk } \\
\text { beroperasi. }\end{array}$ \\
\hline 4 & Material & $\begin{array}{l}\text { - Melengkapi karet pisau yang belum tersedia dengan ukuran yang beragam } \\
\text { sesuai dengan kebutuhan pengerjaan order. } \\
\text { - Koordinasi dengan bagian engineering untuk merekayasa supaya ring dan } \\
\text { pisau mesin dibuat sedemikian rupa yang lebih ringan atau dibuat alat bantu } \\
\text { untuk memudahkan operator agar tenaganya tidak banyak terkuras ketika } \\
\text { proses penyetelan bongkar pasang. }\end{array}$ \\
\hline
\end{tabular}

\section{Kesimpulan}

Berdasarkan hasil penelitian yang telah dilakukan di PT. ABC pada stasiun kerja slitter telah didapatkan nilai availability sebesar 77,3\%, nilai performance sebesar $99,5 \%$, dan nilai quality sebesar 98,7\%. Sehingga nilai OEE yang dihasilkan adalah sebesar 75,9\%. Nilai tersebut masih berada dibawah standar kelas dunia $(<85 \%)$ karena nilai availability dan quality masih kurang baik. Dari analisis six big losses yang dilakukan telah ditemukan losses yang paling berpengaruh terhadap rendahnya nilai availability yaitu set up and adjustment dengan persentase nilai losses sebesar $20 \%$. Melalui analisis diagram fishbone ditemukan sumber utama penyebab rendahnya nilai availability ditinjau dari aspek manusia, metode, mesin dan material. Berbagai tindakan perbaikan diusulkan dengan harapan mampu memperbaiki dan meningkatkan efektivitas mesin slitter.

\section{Referensi}

[1] M. Darsin, "APLIKASI OVERALL EQUIPMENT EFFECTIVENESS (OEE) DALAM UPAYA MENGATASI TINGGINYA DOWNTIME PADA STASIUN KETEL DI PG X JAWA TIMUR," MULTITEK INDONESIA, vol. 13, no. 2, pp. 95-103, 2020. 
[2] E. Rimawan and A. Raif, "Analisis Pengukuran Nilai Overall Equipment Effectiveness (Oee) pada Proses Packaging di Line 2 (Studi Kasus PT. Multi Bintang Indonesia. Tbk)," Sinergi, vol. 20, no. 2, pp. 140-148, 2016.

[3] I. Pratiwi, "Usulan Penerapan Total Productive Maintenance pada Mesin Turbin Gas," Jurnal Optimasi Sistem Industri, vol. 18, no. 1, pp. 37-47, 2019.

[4] D. Alvira, Y. Helianty, and H. Prassetiyo, "USULAN PENINGKATANOVERALL EQUIPMENT EFFECTIVENESS (OEE) PADA MESINTAPPING MANUAL DENGAN MEMINIMUMKAN SIX BIG LOSSES," Reka Integra, vol. 3, no. 3, 2015.

[5] S. Nakajima, "Introduction to TPM: total productive maintenance.(Translation)," Productivity Press, Inc., 1988, p. 129, 1988.

[6] B. Dal, P. Tugwell, and R. Greatbanks, "Overall equipment effectiveness as a measure of operational improvement-a practical analysis," International Journal of Operations \& Production Management, 2000.

[7] R. Rahmad, P. Pratikto, and S. Wahyudi, "Penerapan Overall Equipment Effectiveness (Oee) Dalam Implementasi Total Productive Maintenance (TPM)(Studi Kasus di Pabrik Gula PT."Y”.)," Rekayasa Mesin, vol. 3, no. 3, pp. 431-437, 2012. 